\title{
A comparative study between cilnidipine and amlodipine on learning and memory in albino mice
}

\author{
Veena H., Narendranath S.*, Shashikala G. H.
}

Department of Pharmacology, JJM Medical College, Davangere, Karnataka, India

\author{
Received: 23 January 2020 \\ Revised: 07 March 2020 \\ Accepted: 11 March 2020 \\ *Correspondence: \\ Dr. Narendranath S., \\ Email: narendranathdvg@gmail.com
}

Copyright: (C) the author(s), publisher and licensee Medip Academy. This is an open-access article distributed under the terms of the Creative Commons Attribution Non-Commercial License, which permits unrestricted non-commercial use, distribution, and reproduction in any medium, provided the original work is properly cited.

\begin{abstract}
Background: Alzheimer's disease (AD) is the leading cause of dementia, followed by vascular dementia (VaD). Animal studies have shown that amlodipine improves learning and memory. Since, cilnidipine produces lesser side effects than amlodipine, and animal studies have shown that it has neuroprotective action, this study was conducted to evaluate the effect of cilnidipine on learning and memory and its comparison with amlodipine in alprazolam induced amnesic albino mice.

Methods: This study was carried out on albino mice, divided into three groups of six animals each. Amnesia was induced by intraperitoneal injection of alprazolam in all the three groups from day 1 to 14 . In addition, group 1, 2 and 3 received normal saline as a control, amlodipine and cilnidipine as test drugs respectively, by same route for the same duration. Then, learning and memory of the animals was assessed using elevated plus maze and cook's pole climbing models. Results were compared among the groups using one-way ANOVA followed by post hoc Tukey's test.

Results: In both the model's amlodipine and cilnidipine groups showed statistically significant reduction in transfer latency and conditioned avoidance response duration in comparison with normal saline. But no difference was found between amlodipine and cilnidipine groups.

Conclusions: Cilnidipine and amlodipine showed a non-inferiority response on learning and memory enhancing effect in this study. Since, cilnidipine has lesser side effects than amlodipine, it can be taken up for evaluating its effect on cognitive improvement in dementia patients.
\end{abstract}

Keywords: Cilnidipine, Amlodipine, Transfer latency, Dementia

\section{INTRODUCTION}

Learning is defined as a change in behaviour due to experience which enables to adopt to recent living conditions. It is a process by which brain acquires new information about the events occurring in the given surroundings. ${ }^{1}$ Memory is a fundamental process, and without which we are capable of nothing but simple reflexes and stereotype behaviours. It is a faculty by which sensations, impressions, and ideas are stored and recalled. ${ }^{2}$
Dementia is defined as an acquired deterioration in cognitive abilities that impairs the successful performance of daily living activities. Dementia affects about $7 \%$ of world's population over the age of 65 years, progressively increase with age. The leading cause of dementia is Alzheimer's disease (AD), followed by vascular dementia ( $\mathrm{VaD})$. Approximately $5 \%$ of population over the age of 70 years have AD. Alzheimer's disease is a severe progressive neurodegenerative brain disorder. The first symptom to manifest in $\mathrm{AD}$ is memory loss. Mutations in the three genes have been identified as causes of early onset of 
AD. APP which encodes amyloid beta $(A \beta)$ precursor protein and PSEN 1 and 2, encoding presenilin 1 and 2 respectively. The pathological hall mark of $\mathrm{AD}$ are amyloid plaques, which are extracellular accumulation of $\mathrm{A} \beta$ protein and intracellular neurofibrillary tangles composed of the microtubules associated protein tau. ${ }^{3}$

Mechanisms by which $\mathrm{A} \beta$ and tau induce neuronal dysfunction and death may include direct impairment of synaptic transmission and plasticity, excitotoxicity, oxidative stress and neuroinflammation. The medial temporal lobe, which includes entorhinal cortex and hippocampus are the most vulnerable brain regions to neuronal dysfunction and cell loss in AD. There is no disease-modifying therapy available for $\mathrm{AD}$ at present. Current treatment is aimed to ease symptoms. Donepezil, rivastigmine and galantamine are reversible anticholinesterases and memantine a NMDA receptor blocker are the drugs approved by the FDA for the treatment of AD. But there are many side effects like GIT symptoms, altered sleep with unpleasant dreams, bradycardia and muscle cramps are associated with these drugs. 3,4

Vascular dementia is associated with cerebrovascular disease. Individuals who have had stroke may develop chronic cognitive deficits, which is commonly called as multi-infarct dementia, it occurs due to intracranial atherosclerosis. Many patients with multi-infarct dementia have a history of hypertension, diabetes, coronary artery disease or other manifestations of widespread atherosclerosis. Currently, there is no treatment available for recovery of lost cognition. ${ }^{4}$

In $\mathrm{AD}, \mathrm{A} \beta$ protein increases calcium influx, which leads to an impairment of synapse physiology or even cell death. A number of studies have shown that calcium channel blockers (CCBs) prevent this $A \beta$ induced calcium influx. ${ }^{5}$

CCBs are the most commonly prescribed drug classes for cardiovascular disorders (CVDs) such as hypertension (HTN). One of the commonly used CCBs is Amlodipine. Amlodipine is a long-acting $\mathrm{CCB}$, belongs to dihydropyridine class. It has been shown to reverse experimentally induced amnesia and ameliorate the effects of brain lesions on learning and memory. This is probably either due to inhibition of free radicals-induced damage to cell membrane by increasing blood supply to the brain or due to modulation of L-type of voltage dependent calcium channel blockade. Cilnidipine also belongs to same class as amlodipine and has shown equal efficacy in reducing blood pressure in hypertensive individuals. It blocks both $\mathrm{N}$ and L-type of calcium channels, and associated with lower incidence of pedal oedema compared to amlodipine. A study done by Akira Takahara et al, suggested that cilnidipine by blocking Ntype calcium channel, produces neuroprotective action in animal models. ${ }^{6}$
Hence, this study was conducted to evaluate the effect of cilnidipine on learning and memory, and comparison with amlodipine in alprazolam induced amnesic albino mice using elevated plus maze and cook's pole climbing methods.

\section{METHODS}

Albino mice were obtained from JJM Medical College, animal house attached to the department of pharmacology. Animals were fed standard pellet diet and water. The experiment was conducted for 15 days according to the CPCSEA norms after obtaining the approval of the Institutional Animal Ethics Committee (Ref No.- JJMMC/IAEC/19-2019). They were acclimatized for 7 days before commencement of study in standard laboratory condition $12 \mathrm{~h}$ day and night rhythm, maintained at $21 \pm 1^{\circ} \mathrm{C}$.

\section{Animals}

Total 36 healthy albino mice aged 3-4 months, weighing 20-30 gm of both sexes, previously unused were included, pregnant and diseased animals were excluded.

\section{Doses of drugs used}

Cilnidipine (10 $\mathrm{mg} / \mathrm{kg})$, normal saline $(10 \mathrm{ml} / \mathrm{kg})$, amlodipine $(10 \mathrm{mg} / \mathrm{kg})$, and alprazolam $(0.5 \mathrm{mg} / \mathrm{kg})^{7,8,9}$

\section{Procedure}

Screened animals were divided into 3 groups of 6 animals each. Group 1 received alprazolam $(0.5 \mathrm{mg} / \mathrm{kg}$ i.e., dissolved in saline solution) and normal saline $(10 \mathrm{ml} / \mathrm{kg}$ i.p.), group 2 received alprazolam $(0.5 \mathrm{mg} / \mathrm{kg}$ i.p. dissolved in saline solution) and amlodipine $(10 \mathrm{mg} / \mathrm{kg}$ i.p. dissolved in saline solution) and group 3 received alprazolam $(0.5 \mathrm{mg} / \mathrm{kg}$ i.p. dissolved in saline solution $)$ and cilnidipine $(10 \mathrm{mg} / \mathrm{kg}$ i.p. dissolved in saline solution) every day morning for 14 days. Experiments were carried out on $14^{\text {th }}$ and $15^{\text {th }}$ day between 9.00 am and $3.00 \mathrm{pm}$. Learning and memory activity was assessed by elevated plus maze and Cook's pole climbing methods. ${ }^{10,11}$

\section{Elevated plus maze method}

Maze are the traditional tools in assessing learning and memory performance in laboratory animals. These are used to measure the cognitive performance, notably to evaluate the spatial long-term memory in mice and rats. The apparatus for mice consists of open arms measuring $16 \times 5 \mathrm{~cm}$ and two enclosed arms measuring $16 \times 5 \times 12 \mathrm{~cm}$ with an open roof, arranged so that the two open arms and two enclosed arms are opposite to each other. The maze is elevated to a height of $25 \mathrm{~cm}$.

Transfer latency (TL) is the parameter of memory in this model. The transfer latency is defined as the time in 
seconds taken by the animal to move into one of the enclosed arms. After training the animals for 14 days, experiment is performed in 2 stages. On day 14, the day of acquisition testing, which is performed after 90 minutes of test drug administration, each mouse is placed at the end of an open arm facing away from the centre and TL is recorded.

All four legs inside the closed arm is counted as an entry. Cut off time allotted for each mouse is 90 seconds. Those animals which cannot enter the closed arms within the cut off time are excluded from the study. Retention testing is conducted after $24 \mathrm{~h}$ i.e. on $15^{\text {th }}$ day after the acquisition test and transfer latency is recorded in a similar manner as mentioned before. Shortened TL on $15^{\text {th }}$ day is considered as an index of improvement of memory.

\section{Cook's pole climbing method}

This method is used to study cognitive function, mainly to examine long term memory by negative reinforcement. The apparatus has an experimental chamber $(25 \times 25 \times 25 \mathrm{~cm})$ with the floor grid in a soundproof enclosure. Scrambled shock $(1.5 \mathrm{~mA})$ is delivered to the grid floor of the chamber composed of stainless-steel rods. A pole $2.5 \mathrm{~cm}$ in diameter, hangs inside the chamber through a hole in the upper centre of the chamber. The study mouse is placed in the chamber and allowed to explore the chamber for 45 seconds.

Conditioned stimulus i.e. buzzer signal is turned on and unconditioned stimulus i.e. electric shock is delivered through a grid floor for 5 seconds. Animal learns to associate the buzzer with the impending foot shock and try to avoid the foot shock by climbing the pole after buzzer signal. Avoidance response is defined as climbing reaction time (cut off $<10$ seconds); and escape response is climbing after applying reaction time $>10$ seconds.
All the animals are trained prior to commencing the study, till they acquire $100 \%$ conditioned avoidance response (CAR). The animals are tested for acquisition of memory on day 14 after 90 minutes of drug administration and retention test performed on $15^{\text {th }}$ day. Reduction in CAR duration on $15^{\text {th }}$ day is considered as an index of improvement of memory.

\section{Statistical analysis}

All the data were evaluated statistically with SPSS software. The transfer latency and conditioned avoidance response duration were represented as mean $\pm \mathrm{SD}$ and compared using one-way ANOVA among groups. For intergroup comparison post hoc Tukey's test was performed. Difference was considered as significant at $\mathrm{p} \leq 0.05$.

\section{RESULTS}

\section{Elevated plus maze (EPM) test results}

In group 1 mean \pm SD $\mathrm{TL}$ after 90 minutes of drug administration was $33.67 \pm 7.92$ seconds and after 24 hours was $46.17 \pm 9.6$ seconds, group 2 was $18.8 \pm 8.68$ and $8.67 \pm 4.08$ seconds and group 3 was 20.8 \pm 6.99 and $9.00 \pm 2.76$ seconds respectively. Thus, there was shortening of TL after 24 hours in both group 2 and 3 but, TL increased in group 1. ANOVA test showed $\mathrm{p}<0.000$, thus change in TL after 24 hours was highly significant among the groups. But, after post hoc Tukey's test $\mathrm{p}$ values between group 1 and 2 was $p=0.000$, between group 1 and 3 was $p=0.000$ and between group 2 and 3 was $\mathrm{p}=0.911$. Thus, highly significant difference was found between group 1 and 2 as well as group 1 and 3, whereas difference was insignificant between group 2 and 3. Results have been shown in Table 1 and 2.

Table 1: Comparison of mean TL among 3 groups in EPM model.

\begin{tabular}{|c|c|c|c|c|}
\hline Groups & Drugs & $\begin{array}{l}\text { Mean } \pm \text { SD TL (in } \\
\text { seconds) after } 90 \mathrm{~m}\end{array}$ & $\begin{array}{l}\text { Mean } \pm \text { SD TL (in } \\
\text { seconds) after } 24 \mathrm{~h}\end{array}$ & ANOVA \\
\hline 1 & Normal saline and alprazolam & $33.67 \pm 7.92$ & $46.17 \pm 9.6$ & \multirow{3}{*}{$\begin{array}{l}38.46 \\
{ }^{* *} \mathrm{p}<0.000 \\
\text { highly significant }\end{array}$} \\
\hline 2 & Alprazolam and amlodipine & $18.8 \pm 8.68$ & $8.67 \pm 4.08$ & \\
\hline 3 & Alprazolam and cilnidipine & $20.8 \pm 6.99$ & $9.00 \pm 2.76$ & \\
\hline
\end{tabular}

Table 2: Post hoc Tukey's multiple comparison test showing change in TL between different groups.

\begin{tabular}{|lll|}
\hline Groups & P values & Significance \\
\hline $\mathbf{1}$ v/s 2 & 0.000 & Highly significant $^{*}$ \\
\hline $\mathbf{1}$ v/s 3 & 0.000 & Highly significant \\
\hline $\mathbf{2}$ v/s 3 & 0.911 & Not significant \\
\hline
\end{tabular}

*p=0.000; ${ }^{+} \mathrm{p}=0.000$.

\section{Cook's pole climbing test results}

In group 1 mean \pm SD CAR after 90 minutes of drug administration was $17.33 \pm 12.92$ seconds and after 24 hours was $28.67 \pm 15.92$ seconds, group 2 was $1.5 \pm 0.54$ and $1.167 \pm 0.41$ seconds and group 3 was $2.5 \pm 0.54$ and $1.50 \pm 0.54$ seconds respectively. Thus, there was shortening of CAR duration after 24 hours in group 2 and 3 but, CAR duration increased in group 1. ANOVA test showed $\mathrm{p}<0.004$, thus change in CAR duration after 24 hours was highly significant among the groups. But, after 
post hoc Tukey's test $\mathrm{p}$ values between group 1 and 2 was $\mathrm{p}=0.010$, between group 1 and 3 was $\mathrm{p}=0.007$ and between group 2 and 3 was $p=0.997$. Thus, highly significant difference was found between group 1 and 2 as well as group 1 and 3, whereas difference was insignificant between group 2 and 3. Results have been shown in Table 3 and 4.

Table 3: Comparison of mean CAR among 3 groups in EPM model.

\begin{tabular}{|c|c|c|c|c|}
\hline Groups & Drugs & $\begin{array}{l}\text { Mean } \pm \text { SD CAR (in } \\
\text { seconds) after } 90 \mathrm{~m}\end{array}$ & $\begin{array}{l}\text { Mean } \pm \text { SD CAR (in } \\
\text { seconds) after } 24 \mathrm{~h}\end{array}$ & ANOVA \\
\hline 1 & Normal saline and alprazolam & $17.33 \pm 12.92$ & $28.67 \pm 15.92$ & \multirow{3}{*}{$\begin{array}{l}6.136 \\
{ }^{* *} \mathrm{p}<0.004 \\
\text { highly significant }\end{array}$} \\
\hline 2 & Alprazolam and amlodipine & $1.5 \pm 0.54$ & $1.167 \pm 0.41$ & \\
\hline 3 & Alprazolam and cilnidipine & $2.5 \pm 0.54$ & $1.50 \pm 0.54$ & \\
\hline
\end{tabular}

Table 4: Post hoc Tukey's multiple comparison test showing change in CAR between different groups.

\begin{tabular}{|lll|}
\hline Groups & P values & Significance \\
\hline $\mathbf{1}$ v/s 2 & 0.010 & Significant $^{*}$ \\
\hline $\mathbf{1}$ v/s 3 & 0.007 & Highly significant \\
\hline $\mathbf{2}$ v/s 3 & 0.997 & Not significant \\
\hline * $=0.010 ; * * p=0.007$ & \\
\hline
\end{tabular}

\section{DISCUSSION}

This study was conducted to evaluate the effect of cilnidipine on learning and memory and compare with amlodipine in alprazolam induced amnesic albino mice.

In EPM model, both group 2 and 3 showed significant shortening of TL after 24 hours of drug administration compared to group 1, but after post hoc Tukey's test $\mathrm{p}$ value between 2 and 3 was $p=0.911$, which shows insignificant difference between the two groups. In CPC model, also both group 2 and 3 showed significantly shortened CAR duration after 24 hours compared to group 1, but after post hoc Tukey's test $\mathrm{p}$ value between group 2 and 3 was $\mathrm{p}=0.997$, which shows insignificance.

Thus, the present study showed both cilnidipine and amlodipine have memory enhancing effect, but significant difference was not found when cilnidipine was compared with amlodipine, this shows both cilnidipine and amlodipine have equal effect on learning and memory improvement. A study done by Quarterman et.al, also showed that amlodipine can facilitate memory consolidation and retrieval. ${ }^{12}$

Intracellular calcium overload is detrimental to neuronal function. In $\mathrm{AD}, \mathrm{A} \beta$ protein increases calcium influx, which leads to an impairment of synapse physiology or even cell death. A number of studies have shown that CCBs prevent this $A \beta$ induced calcium influx. They also improve the cerebrovascular perfusion by relaxing smooth muscle cells in the brain capillaries. Cilnidipine inhibits both L and N-type of voltage dependent calcium channels and is associated with lower incidence of side effects compared to amlodipine. ${ }^{13}$ A study conducted by Takahara et al, showed that cilnidipine has neuroprotective action due to its $\mathrm{N}$-type calcium channel blocking property.

After literature survey, it was found that, this is the first study to evaluate effect of cilnidipine on learning and memory and compare its effect with amlodipine in alprazolam induced amnesic mice.

\section{CONCLUSION}

In this study, both cilnidipine and amlodipine have shown learning and memory enhancing effect, but significant difference was not found between them. Since, cilnidipine produces lesser side effects compared to amlodipine, it can be preferred over amlodipine. Hence, clinical studies can be considered to evaluate the effect of cilnidipine on cognitive improvement in dementia patients.

\section{Funding: No funding sources}

Conflict of interest: None declared

Ethical approval: The study was approved by the Institutional Ethics Committee

\section{REFERENCES}

1. Buss DM, Greiling $H$. Adaptive individual differences. J Personality. 1999;67:209-43.

2. Okano H, Hirano T, Balaban E. Learning and Memory. PNAS. 2000;97(23):12403-4.

3. William W. Seeley, Bruce L. miller. Alzheimer's disease and other dementias. In: Kasper DL et al, eds. Harrison's principles of internal medicine.19th ed. New York. NY: McGraw-Hill; 2015: 2598-2601.

4. Erik DR. Treatment of central nervous system degenerative disorders. In: Brunton LL, Dandan HR, Knollmann BC, eds. Goodman and gilman's the pharmacological basis of therapeutics. 13th ed. New York, NY: McGraw-Hill; 2018: 327-338.

5. Nimmrich V, Eckert A. Calcium channel blockers and dementia. BJP. 2013;169:1203-10.

6. Takahara A, Konda T, Enomoto A, Kondo N. Neuroprotective effect of a dual L/N type calcium channel blocker Cilnidipine in the rat focal brain ischaemia model. Biol Pharm Bull. 2004;27(9):138891. 
7. Kumar N, Singh N, Jaggi AS. Antistress effect of Cilnidipine and nimodipine in immobilization subjected mice. Physiol Behav Epub. 2011;105(5):1148-55.

8. Grazyna B, Marta KS, Krzysztof J. Influence of acute or chronic calcium channel antagonists on the acquisition and consolidation of memory and nicotinie-induced cognitive effects. NaunynSchmiedeberg's Arch Pharmacol. 2013;386:651-64.

9. Nitin Bansal, Milind Parle, Effect of soybean supplementation on the memory of alprazolaminduced amnesic mice. J Pharmacy Bio Allied Sci. 2010;2(2):144-7.

10. Hall FS, Yasir S. Drug effect on learning and memory in: Franz J. Hock eds. Drug discovery and evaluation: Pharmacological Assays. 4th ed. New York, NY: Springer; 2016: 1625-1675.

11. Prasad P, Kulkarni M, Bhave K. Effect of amlodipine and metoprolol on cognition in rats. Int $\mathrm{J}$ Recent Trends Science Technol. 2016;18;(1):156-62.
12. Quartermain D, Hawxhurst A, Ermita B, Puente J. Effect of calcium channel blocker amlodipine on memory in mice. Behav Neural Biol. 1993;60:211-9.

13. Nagahama S, Norimatsu T, Maki T, Yasuda M. The effect of combination therapy with an L/N-type calcium channel blocker, Cilnidipine and Angiotensin II Receptor Blockers on the blood pressure and heart rate in Japanese hypertensive patients: an observational study conducted in Japan. Hypertens Res. 2007;30(9):815-22.

Cite this article as: Veena $\mathrm{H}$, Narendranath $\mathrm{S}$, Shashikala GH. A comparative study between cilnidipine and amlodipine on learning and memory in albino mice. Int $\mathbf{J}$ Basic Clin Pharmacol 2020;9:726-30. 